\title{
PREVOĐENJE SPECIFIČNIH ELEMENATA POLITIČKE I PRAVNE KULTURE U NJEMAČKOM I HRVATSKOM JEZIKU
}

\author{
Vesna Ivančević Ježek* \\ Filozofski fakultet Sveučilišta u Zagrebu \\ Monika Blagus* \\ Filozofski fakultet Sveučilišta u Zagrebu
}

U ovome se radu na nizu primjera hrvatskih i njemačkih političkih i pravnih termina poput Bundesland i javni pravobranitelj raščlanjuju problemi koje prevoditelj mora rješavati ako ne postoji adekvatan paralelni koncept ili prijevodni ekvivalent na drugom jeziku. Kao važne pretpostavke za dobar prijevod takvih termina utvrđuju se temeljita upućenost u pravni i politički poredak i terminologiju obiju kultura i posebno poznavanje značenja, prepoznavanje homonimije i pripadnosti određenog termina određenom političkom ili pravnom poretku te ispravna procjena razumljivosti uz nezaziranje od primjerene količine učenja prijevodom. Rad također ukazuje na nekoliko čestih pogrešaka i moguću motivaciju netočnih prijevoda političkih ili pravnih termina.

\section{Ključne riječi: prevođenje njemačkih $i$ hrvatskih političkih i pravnih termina, homonimija, politički ili pravni poredak, razumljivost, egzotizam}

\section{UVOD}

Ovaj je rad posvećen pitanju kako pristupiti pravnim ili političkim terminima na njemačkom i hrvatskom jeziku za koje ne postoji paralelni izraz u drugom jeziku.

Najprije valja istaknuti da je broj posve paralelnih izraza iz područja prava i politike u njemačkom i hrvatskom jeziku vrlo velik budući da pravni i politički poretci Republike Hrvatske s jedne i Njemačke i Austrije s druge strane svoje nazivlje u značajnoj mjeri crpe iz zajedničkog pravnog izvora u rimskom pravu. Paralelizmi poput na ovome mjestu nasumce odabranog pojma "stvarnog prava“ (Sachenrecht) stoga su uobičajeni. Sličnosti sustava nadalje se mogu objasniti i činjenicom dugog razdoblja pripadanja istoj, tj. austrijskoj i austro-ugarskoj državnoj zajednici i utjecaju njezinih zakona, posebno Općeg građanskog zakonika (ABGB). ${ }^{1}$

\footnotetext{
* vivancev@ffzg.hr

** mblagus@ffzg.hr

1 Usp. M. Petrak (2014): „U novije vrijeme rimsko pravno naslijeđe bilo je prisutno u Hrvatskoj prije svega zahvaljujući odredbama austrijskog Općega građanskog zakonika (ABGB) iz 1811. godine, čije je važenje tijekom 19. st. protegnuto na gotovo sve hrvatske krajeve.“
} 
Kada paralelni izraz ne postoji, u prevoditeljskoj praksi mogu nastati problemi između ostaloga zato što se pogrešno detektira prividni paralelizam među dvama izrazima, a zapravo se, bar djelomično, radi o lažnim prijateljima (primjer 2.1.), zato što je značenje termina na izvornom jeziku pogrešno ili nepotpuno shvaćeno ili interpretirano (primjeri 3.2.; 3.4.; 3.5.; 3.8.), zato što se prevoditelj ustručava upotrijebiti termin koji smatra neuobičajenim (primjer 3.3.) ili zato što je teško procijeniti pouzdanost terminoloških izvora (primjer 3.7.).

\section{O PREVOĐENJU POLITIČKIH I PRAVNIH TERMINA}

Politika i pravo specifične su i kompleksne discipline upravo zbog toga što su duboko ukorijenjene u povijesni okvir, tradiciju, kulturu, sustave vrijednosti i ideološku orijentaciju pojedinih naroda. Zbog te činjenice nije tako čudno da ne postoje dva ista politička ili pravna sustava. To se, naravno, reflektira i na jezik tih struka, zbog čega se ne može govoriti o jednom homogenom jeziku prava ili jeziku politike. Čak se ne može govoriti ni o primjerice zajedničkom njemačkom pravnom jeziku, već su različite okolnosti i odnosi doveli do toga da postoje razlike između austrijsko-njemačkog, saveznonjemačkonjemačkog, švicarsko-njemačkog, lihtenštajnsko-njemačkog, belgijskonjemačkog i luksemburško-njemačkog jezika te struke. Posljedice su toga da postoji određeni broj pravnih i političkih termina koji su specifični za samo jedan pravni ili politički sustav. Za njih, u znanosti o prevođenju naziva ih se kulturemima (Hansen, 1996), realijama (Markstein, 2006) ili pak, prema engl. culture words, riječima koje izražavaju kulturu (Ivir, 1987; Newmark, 1988), važno je znati da ne postoje prijevodne istovrijednice $u$ drugim jezicima. $\mathrm{S}$ druge strane između pravnih i političkih termina u različitim jezicima ne može postojati potpuna pojmovna podudarnost (de Groot, 1991: 287; Sandrini, 1996: 141) $)^{2}$.

Navedene specifičnosti pravnog i političkog jezika svakako utječu na kompliciranost procesa prevođenja, odnosno prevoditelju mogu otežati donošenje ispravne odluke kod izbora istovrijednica. Unatočtome, prevoditelj kod prevođenja primjerice pravnih tekstova treba biti sposoban osigurati isti pravni učinak i očuvati pravnu sigurnost ciljnog teksta (Sandrini, 1999: 39). Dakle treba biti u stanju premostiti barijeru u razumijevanju između autora izvornog i čitatelja ciljnog teksta. Da bi to postigao, prevoditelj, dakako, treba biti dovoljno kompetentan, što znači da izvrsno poznaje jezike i kulture kojima se bavi, da posjeduje dovoljno stručnog znanja o pravnim i političkim sustavima te da izvrsno vlada vještinama koje su specifične za samu prevoditeljsku struku.

\footnotetext{
${ }^{2}$ Potpuna pojmovna podudarnost moguća je samo kod termina koji pripadaju različitim jezicima, ali se odnose na pravni ili politički sustav iste države (Belgija, Kanada, Finska, Švicarska).
} 


\subsection{Metode za učinkovito prevođenje pravnih i političkih termina}

Zbog dimenzije zadatka koji treba riješiti, odnosno specifičnih zahtjeva koji stoje pred prevoditeljima, a radi se o činjenici da kod prevođenja političkih i pravnih termina nije dovoljno poznavanje njihove funkcionalne istovrijednice $\mathrm{u}$ drugom jeziku, tj. termina koji ispunjava sličnu funkciju kao i ishodišni termin (Šarčević, 1989: 278), u pripremi provođenja procesa prevođenja mogu se primijeniti određeni pristupi, kao što su primjerice prijevodni princip „zajedničkog minimuma u značenju“ (Bleckmann, 1977: 99 cit. prema Stolze, 1992: 225) te princip "transparentnog prevođenja“.

Prema principu "zajedničkog minimuma u značenju“, prevoditelj bi prije samog prevođenja trebao razumjeti svaki pravni, $t j$. politički termin $u$ tekstu, što podrazumijeva sagledavanje opsega i sadržaja njegova pojma kao misaone kategorije te određivanje njegova mjesta u pravnom, tj. političkom sustavu izvornog jezika. Isto se takvo razumijevanje zahtijeva i za njegove moguće istovrijednice, kako bi se usporedile sličnosti i razlike među njihovim pojmovima i kako bi se na temelju toga pronašao naziv s najvećim zajedničkim minimumom u njihovu značenju (v. primjere 3.2., 3.6. i 3.8).

Princip „transparentnog prevođenja“ polazi od toga da prevoditelj treba razumjeti pravo značenje pojedinih jezičnih elemenata te cijelog teksta na izvornom jeziku, kako bi na taj način mogao nepoznate termine u ciljnom jeziku prikazati na razumljiv način te time čitatelju ciljnog teksta doista omogućiti razumijevanje izvanjezične situacije predstavljene $u$ izvornom tekstu (Stolze, 1992: 227-229).

Dakako, najveći izazov kod pravnog i političkog prevođenja zasigurno predstavlja prevođenje kulturno specifičnih termina za koje u drugim jezicima ne postoji prijevodna istovrijednica. Kod takvih prijevodnih problema de Groot (1999: 208) preporučuje primjenu jednog od triju mogućih postupaka, koji se primjenjuju i kod prevođenja kulturno specifičnih termina općenito ${ }^{3}$ (usp. Markstein, 2006: 291, Pavlović, 2015: 73-81):

a) preuzimanje izvornog naziva iz ciljnog jezika eventualno uz doslovan prijevod u zagradi ili parafrazu u bilješci (v. primjere 3.1., 3.2., 3.3. i 3.6.)

b) objašnjenje naziva izvornog jezika u ciljnom jeziku, čime nastaje deskriptivna istoznačnica (v. primjere 3.5. i 3.8.)

c) uvođenje novog izraza tj. neologizma ${ }^{4}$, eventualno uz pojašnjenje $u$ bilješci (v. primjer 3.2.)

\footnotetext{
${ }^{3}$ Neki od postupaka pri prevođenju kulturno specifičnih termina jesu posuđivanje ili preuzimanje stranog naziva uz eventualnu prilagodbu pravopisu ciljnog jezika, doslovan prijevod ili kalk, kulturni ekvivalent ili zamjena naziva u izvornom jeziku nazivom koji ima slično značenje u ciljnom jeziku, opisni prijevod, dodavanje kratkog objašnjenja, izostavljanje i neologizam.

${ }^{4}$ Za de Groota (1999: 209) neologizam može biti bilo koji izraz koji ne pripada pravnom sustavu ciljnog jezika.
} 


\subsection{Pretpostavke odabira prevoditeljskog postupka}

Do 80-ih godina 20. stoljeća kod prevođenja se smatralo najvažnijim tekstualni materijal na jednom jeziku zamijeniti ekvivalentnim tekstualnim materijalom na drugom jeziku (Catford, 1965: 20), pri čemu je izvorni tekst bio najvažniji dio tog procesa. No od tada se fokus premješta na funkciju, tj. svrhu (skopos) prijevoda u ciljnoj situaciji. To povlači za sobom davanje veće važnosti ulozi i kompetencijama prevoditelja. Prevoditelj tako postaje ključni element prijevodnog procesa. Od njega se zahtijeva da razumije izvorni tekst i namjeru njegova autora te da ga uz svoje jezično, kulturno i stručno znanje prilagodi očekivanjima čitatelja u drugoj kulturi, a često i drugačijoj situaciji. Jedna od značajnih sudionica u promjeni perspektive $u$ znanosti o prevođenju i jedna od glavnih zastupnica tzv. teorije skoposa, Katharina Reiß, ustanovila je da se namjera autora ne prenosi samo sadržajem, već i formom teksta, tj. tekstnom vrstom. Shodno tomu, Reiß je u knjizi "Grundlegung einer allgemeinen Translationstheorie“" (Reiß i Vermeer, 1984) osmislila klasifikaciju tekstnih vrsta upravo prema njihovoj svrsi. Na taj su se način mogla lakše iznaći adekvatna rješenja korištenja različitih tekstova i njihova funkcioniranja ovisno o okolnostima. Značaj takve klasifikacije za prevođenje sastoji se u tome što pripadnost određenog teksta jednoj od triju tekstnih vrsta određuje primjenu određenih prijevodnih postupaka. Tako je kod tzv. informativnih tekstova, koji obuhvaćaju stručne, znanstvene i novinske tekstove te dokumente, svrha prenošenje određenog sadržaja. To znači da bi kod prevođenja takvih tekstova sadržaj izvornog i ciljnog teksta trebali biti što sličniji. U usporedbi s tim, kod ekspresivnih tekstova, u koje se ubrajaju književni tekstovi, u prvom je planu estetsko djelovanje, zbog čega je najvažnije da prevoditelji zadrže individualni karakter originala. Kod operativnih tekstova, u koje se primjerice ubrajaju politički govori, tj. tekstovi kojima se kod primatelja/čitatelja pokušava potaknuti određeno ponašanje i u kojima je u prvom planu apel, prevoditelji bi trebali sve elemente ponajprije podrediti izazivanju istih reakcija kod čitatelja ciljnog teksta i čitatelja izvornog teksta (Reiß i Vermeer, 1984: 204-216).

U nastavku članka na primjerima naziva kao što su Bundesland i državna cesta prikazat će se primjenjivost u ovom poglavlju spominjanih navoda, shvaćanja i uvjeta te će se na temelju usporedbi njemačkih i hrvatskih termina za koje se može zaključiti da kod njih nisu dovoljno precizno primijenjeni prijevodni principi „,zajedničkog minimuma u značenju“ te „transparentnog prevođenja“, što je dovelo do toga da ne prenose pravo značenje termina iz izvornog jezika i kulture, predložiti primjerenija prijevodna rješenja. 


\section{PRIMJERI}

\subsection{Reich - skrivena homonimija}

Prvi primjer na kojemu ćemo ovdje raščlaniti slojevitost značenja je njemačka imenica Reich. Prijevod je neproblematičan kada se javlja u značenju carstva ili kraljevstva kao što je to slučaj kod Römisches Reich (Rimsko Carstvo) ili Heiliges Römisches Reich Deutscher Nation (Sveto Rimsko Carstvo Njemačke Narodnosti). Stvar se usložnjava s pojmom Deutsches Reich, koji je službeno trajao od 1871. do 1943., a do 1945. godine službeno je to bio Großdeutsches Reich. Prijevod izrazom "carstvo“ ispravan je samo do 1918. Nakon toga je očito netočno govoriti o Njemačkom "Carstvu“ kada se radilo o republici, pa bi izrazu Reich zapravo više odgovarala „država“. Često korištenje „carstva“" za fazu republičkog poretka vjerojatno počiva na previdu, odnosno zanemarivanju dijela označenog. Prednost treba dati rješenju koje se uvriježilo budući da postojeći termini ne odgovaraju u potpunosti, a to je preuzimanje njemačkog izraza Reich, pa i u fonetiziranom obliku Rajh. Tako za razdoblje počevši od 1933. godine obično koristimo izraz Treći Rajh/Reich. Redni broj "treći“ odraz je nacističkih težnji da nakon prvog carstva (Svetog Rimskog) i drugog (onog Njemačkog od 1871.) te nakon faze klimave weimarske demokracije uspostave treću imperijalnu vladavinu. Za pojam „Reich“ kao takav treba znati da on određuje ponajprije vladavinu nekim teritorijem /Grimm 1893/, dakle po značenju se najviše poklapa s hrvatskom "državom“, ali bilo bi besmisleno i neprikladno govoriti o "Trećoj Državi“, dok bi se Deutsches Reich za vrijeme Weimarske Republike, kada je to također bio službeni naziv, itekako prikladno moglo prevesti kao "Njemačka Država“.

\subsection{Bundesland - pogrešno shvaćanje}

Sljedeći primjer poslužit će za prikaz uvriježenog, alineutemeljenog prijevoda, a riječ je o nazivu njemačkih federalnih jedinica, Bundesland. Prijevod koji se u prijašnjim vremenima gotovo isključivo rabio, a u medijima je nažalost $i$ dalje vrlo čest glasi „Njemačke savezne pokrajine“.

Možda i nije potrebno detaljnije objasniti zašto to nije valjan prijevod, pa ćemo samo podsjetiti da su to jedinice koje su imale suverenitet osnovati Saveznu Republiku Njemačku, koje imaju svoje ustave, donesene 1946., dakle prije Njemačkog ustava, koje imaju svoje ustavne sudove, svoju policiju, svoje zakonodavstvo, a na važnom području obrazovanja primjerice i dandanas se samo dogovaraju, dok Savezna razina nema zakonodavne ovlasti. ${ }^{5}$

Pokrajina, međutim, koja se kao pojam povezuje s latinskim Provincia, nema takvu samostalnost i kao opći pojam naprosto sadržajno ne odgovara činjenicama. Primijenivši taj prijevod, ponekad bismo dobili apsurdne

\footnotetext{
${ }^{5}$ Usp. o prevođenju toponima Lütze-Miculinić (2004).
} 
rečenice poput: „I onda je savezna pokrajina A promijenila svoj ustav“. Ili da je u Saveznom vijeću pokrajina B glasovala protiv prijedloga Saveznog parlamenta. Još jedan pokazatelj koji upućuje na to da je "pokrajina" pogrešna kategorija nalazimo u činjenici da se službeni listovi Bavarske i Baden-Württemberga zovu "Staatsanzeiger" - dakle „Državni oglasnik/ list", što ne bi bilo spojivo s pokrajinom.

Umjesto pokrajina počela su se javljati dva nova prijevoda, „savezna zemlja“ i "savezna država“. Motivaciju za ovaj drugi prijevod teško je prepoznati osim u činjenici da je to doslovni prijevod uobičajenog engleskog prijevoda koji se koristi analogijom federalnih jedinica Sjedinjenih Američkih Država-međutim, one se upravo tako nazivaju na engleskom, one jesu states. Novinari koji u svojim tekstovima pišu o njemačkim ",saveznim državama“ sasvim sigurno znaju razliku između SAD-a i Njemačke, ali može se pretpostaviti da kao izvore koriste agencijske vijesti na engleskom u kojima se naravno i za njemačke zemlje javlja izraz "federal states“. Nije, međutim, razvidan nijedan razlog zašto bi na hrvatskom prednost trebalo dati izrazu "država“ kada se hrvatska riječ „,zemlja“ semantički gotovo zrcalno poklapa s njemačkim Land. ${ }^{6}$

U specifičnim tekstnim vrstama, primjerice na međunarodnim sudovima, isto je tako moguće zadržati, odn. posuditi njemački izraz Bundesländer u nekom drugom jeziku, kao što se i nazivi sudova preciznosti radi u takvom kontekstu ostavljaju u izvornim obliku. Međutim, i u dokumentima Europskog suda u hrvatskoj jezičnoj inačici može se primijetiti da se kao opći pojam za Bundesland javlja izraz ",savezna zemlja“, što treba pozdraviti (Mišljenje nezavisnog odvjetnika u predmetu C492/17.).

Iz kojeg su se razloga "Savezne pokrajine" tako uporno upotrebljavale teško je procijeniti, međutim ne smijemo zaboraviti da su vremena bila drugačija i da politika u bivšoj Jugoslaviji nije bila ravnodušna prema ideji o samostalnosti federalnih jedinica. Osim toga, u toj je državi zaista i bilo autonomnih pokrajina, pa se nekome moglo učiniti prikladnim upravo tim izrazom prevoditi njemačke teritorijalne jedinice, izmišljajući lažni paralelizam. Doduše, ostaje nejasno zašto onda za paralelizam nije poslužila "republika“, kako su se zvale sastavne jedinice jugoslavenske federacije, što bi politički i pravno bilo daleko bliže pojmu Bundesland.

Prvih godina samostalne Hrvatske činilo se da je zalaganje za izraz „Savezne zemlje“ značilo „ispravljanje krivih Drina“. Međutim, budući da danas u ozbiljnim prijevodima vrlo često nalazimo "Savezne zemlje“ čini se da ipak nije bilo uzalud. Povrh toga, mlađe generacije izraz "pokrajina“ jednostavno više ne doživljavaju kao nešto što im je blisko kao što je to,

\footnotetext{
${ }^{6}$ Kao što je Vladimir Ivir već 1987. ustvrdio, doslovni prijevod treba izbjeći kada u ciljnom jeziku nema smisla, kada ima drugo značenje nego u izvornom jeziku ili je strukturno, gramatički neprihvatljiv (usp. Pavlović, 2015: 75-76).
} 
pretpostavljamo, bilo onima koji su prije 40 godina imali možda i naviku svakodnevno čitati Vjesnik ili gledati vijesti na državnoj televiziji.

Bliskost, osjećaj poznatosti i nezačudnosti inače je kriterij koji se u prevođenju može, pa i treba primijeniti kao kriterij odabira primjerenog izraza, što je primjerice $\mathrm{u}$ skladu s terminološkim načelom prednosti proširenijeg i korisnicima prihvatliivijeg izraza (Hudeček i Mihaljević, 2012: 70), pa donekle i s načelom da se nazive ne treba mijenjati bez valjanog razloga (isto: 75$)^{7}$, ali kršenje denotativne ekvivalencije ${ }^{8}$ do koje je ovdje došlo svakako predstavlja valjan razlog za ustrajanje na točnijem prijevodnom ekvivalentu, jer odabrani termin mora odgovarati izvanjezičnoj stvarnosti.

\subsection{Državna cesta - strah od egzotizma}

Objašnjenje gornje tvrdnje donosi sljedeći primjer. Prevoditelji koji se nađu pred nezahvalnim zadatkom da prevode prometne vijesti za inozemne turiste u Hrvatskoj muku muče s kategorijama cesta na koje se izvještaj o prometnoj situaciji odnosi. Ne ulazeći u pitanje koliko je svrsishodno takve informacije $u$ današnje vrijeme čitati munjevitom brzinom nekome tko vrlo vjerojatno ne može ni prepoznati nazive mjesta, izdvojit ćemo tzv. državne ceste. Kategorija Staatsstraße u njemačkom prometnom sustavu uglavnom ne postoji, osim u Saskoj, što je i Nijemcima malo poznat podatak. U spomenutim prometnim informacijama Hrvatskog radija koje se emitiraju na njemačkom jeziku prevoditelji se nisu usudili iskovati taj termin, jer ga se tako rijetko čuje. Stoga se u hrvatskim prometnim informacijama na njemačkom jeziku povremeno znalo čuti da je gust promet na hrvatskoj "Bundesstraße", iz čega je njemački slušatelj morao zaključiti da je Hrvatska federalna ili savezna država. To bi dakako bio logički sasvim ispravan zaključak, ali realno posve pogrešan te se državnu cestu ne može tako prevesti. Što bi, dakle, bio primjeren prijevod za državnu cestu? Za odgovor na to pitanje prvo moramo utvrditi komunikacijsku situaciju, tekstnu vrstu i njegova adresata, posve u skladu s teorijom skoposa (v. 2.2.). Ako se radi o tekstu koji zahtijeva točnu pravnu kategorizaciju, $\mathrm{u}$ apsolutnom nedostatku paralelnog pojma prijevod može biti opisan, iako je to baš u pravnim tekstovima iz više razloga nepraktično i najčešće neprikladno. Druga je mogućnost da prijevod bude doslovan, odn. u ovom slučaju složenica. Nijedan se njemački pravnik ne bi čudio izrazu Staatsstraße, čak i da ne zna za tu kategoriju u Saskoj, kada bi mu to bilo prezentirano kao dio kategorizacije hrvatskih cesta. Laiku se, naravno, sve što nikada prije nije čuo može činiti egzotičnim. Međutim, pitanje egzotičnosti zapravo je neprimjereno kod termina koji označavaju konkretne pravne institute. Ne možemo prevoditi realije vođeni načelom

\footnotetext{
7 O ekvivalentnom efektu i prirodnosti usp. Pavlović (2015: 47 ff.) o Nidi.

${ }^{8}$ Prvo načelo prijevodne ekvivalentnosti prema Werneru Kolleru (usp. Pavlović, 2015: 50).
} 
izbjegavanja nepoznatoga, jer bismo mijenjali stvarnost i hinili da je pravna kultura zemlje izvornog jezika baš ista onoj zemlje ciljnoga jezika. Ono što treba izbjegavati je nerazumljivost, a to je pak kategorija koja u velikoj mjeri ovisi o predznanju onoga kome je prijevod namijenjen. Koliko god se trudili prilagoditi izraz za pravni termin sposobnostima razumijevanja pravnog laika, ne možemo izrazom nadoknaditi njegovo nepoznavanje prava. Takvo bi nerazumijevanje, uostalom, postojalo $\mathrm{u}$ istoj mjeri za pravne termine na materinskom jeziku i zapravo uopće ne predstavlja problem prijevoda, nego ga prijevod tek čini vidljivim. Glede spomenutih radijskih vijesti najprikladnije rješenje bilo bi da se jednostavno navede kratica, dakle ime dotične ceste i kaže: dichter Verkehr auf der D1, jer tako piše i na autokartama i informacija bi bila razumljiva i svrsishodna za turiste kojima je namijenjena, a izbjegle bi se pogrešne implikacije.

\subsection{Jugoslavenske republike s političkom interpretacijom}

U sljedećem primjeru vratit ćemo se u prošlost, i to u vrijeme postojanja bivše Socijalističke Federativne Republike Jugoslavije. Njezine sastavnice zvale su se socijalističke republike, no u njemačkoj se literaturi govorilo o Sozialistische Teilrepubliken. Odakle prvi konstituent složenice „Teil-,, možemo samo nagađati. Time se svakako naglašavala nesamostalnost tadašnjih 6 republika, ali je ipak neobično da su baš njemački novinari, koji inače tako visoko cijene federalizam i policentrično ustrojstvo, na taj način klasificirali federalne jedinice jedne druge države. Zašto se željelo izbjeći dojam paralelizma kod njemačkih čitatelja koji bi bez onog „Teil-“ mogli pomisliti da su Hrvatska, Slovenija, Srbija itd. nešto poput njihovih Bundesländera? O tom pitanju može se samo nagađati, ali svakako je zanimljivo da su i kod prevođenja federalnih jedinica Njemačke i onih bivše Jugoslavije umjesto stručnih kriterija primijenjeni politički. U usporedbi s tim prošlim vremenima, prijevod hrvatskih županija nakon početnih pomalo čudnovatih kolebanja tijekom 90-ih godina poput „Županien“, Landkreise (što bi predstavljalo zamjensku i stoga politički nepreciznu referenciju) i „Komitaten“ - potonje bi bilo primjerenije za nekadašnje mađarske regije $-\mathrm{s}$ vremenom se ustalio jezično i povijesno prikladan izraz Gespanschaften koji je i ranije postojao u njemačkom jeziku, samo što je iz povijesnih razloga nestankom županija iz zbilje pao u zaborav. Praksa je pokazala da je u njemački tekst ipak bolje uklopiti izraz koji je tvorbeno dio njemačkog jezika, a o značenju recipijenta poučiti, nego bez potrebe preuzeti barem jednako nerazumljivu riječ $s$ dijakritičkim znakom ili neprimjerenom transkripcijom. I u jednom i drugom slučaju recipijent će morati naučiti da se radi o kategoriji teritorijalnog ustrojstva današnje Republike Hrvatske. 


\subsection{Nekadašnji javni pravobranitelj}

Slijedi primjer koji će pokazati koliko je važno znati u koje je vrijeme smješten izraz o kojem govorimo, jer svako vrijeme ima svoje institucije. Kada danas čujemo izraz javni pravobranitelj vjerojatno će nam prvo pasti na pamet nešto poput Ombudsmana, lijepe demokratske institucije koja je uvriježena $u$ naprednim zapadnim zemljama, a sada ih kao članica Europske unije ima i Hrvatska. No, radi li se zaista o tom pojmu? To se može utvrditi na tekstu u kojem je riječ o ,javnom pravobranitelju“ a to je primjerice

\section{„ZAKON O PRODAJI STANOVA NA KOJIMA POSTOJI STANARSKO PRAVO (zadnja izmjena NN 78/02)}

Članak 21.

Prodavatelj je dužan ugovor o prodaji stana dostaviti na mišljenje nadležnom javnom pravobranitelju u roku od 8 dana.

Ako javni pravobranitelj utvrdi da nisu ispunjeni zakonski uvjeti za sklapanje ugovora ili da je ugovorena cijena niža od utvrđene prema odredbama ovoga zakona dostavit će mišljenje da se stan ne može prodati. Ako nakon zaključenja ugovora javni pravobranitelj utvrdi da nisu postojali zakonski uvjeti za sklapanje ugovora, zatražit će poništenje ugovora u roku od godine dana od dana sklapanja ugovora. ..."

Vidimo da se tu govori o postupcima u vezi s ugovorima o prodaji stana koji nemaju veze sa zadatcima bilo kakvog ombudsmana. Kada bismo se upustili u doslovni prijevod: Öffentlicher Rechtsverteidiger, zaista bismo prekršili pravilo razumljivosti i postavili čitatelja pred zagonetku: tko to brani čija prava. Za razliku od primjera sa "Staatsstraßen“ ovdje bi ostao veliki upitnik i kod pravnog znalca, pa treba posegnuti za funkcionalnim, opisnim prijevodom, dakle onim koji tumači čemu je ta institucija služila. Budući da je javni pravobranitelj zastupao imovinske interese javnih tijela - kasnije se zvao i državni pravobranitelj, što pak ne smijemo miješati s državnim odvjetnikom, makar Google translate upravo na to nasjeda - njegove se ovlasti u najvećoj mjeri poklapaju s ovlastima ureda koji se u Njemačkoj zove Liegenschaftsamt. Taj se pak ured bavi upravljanjem nekretnina, a nedostaje mu segment drugih imovinskih interesa, stoga bi razumljiv i točan prijevod glasio Öffentliches Liegenschafts- und Vermögensamt. 


\subsection{Iz socijalističkog poretka}

Također prošlosti pripadaju primjeri poput Centralnog komiteta (CK), poljoprivredno-industrijskog kombinata (PIK), Samoupravne organizacije udruženog rada (SOUR) itd. Za njih ćemo paralelizme naći u bivšem DDR-u, paralelnom jednopartijskom sustavu. Zentralkomitee (ZK) je apsolutni ekvivalent, landwirtschaftliches Industriekombinat bio bi posve razumljiv i prihvatljiv, iako je u DDR-u paralelna organizacija nosila naziv Landwirtschaftliche Produktionsgenossenschaft (LPG). „Udruženi rad“ je tvrđi orah jer je to bila originalna tvorevina bivše Jugoslavije, pa je najbolje to prevesti doslovno: Selbstverwaltende Organisation der vereinten Arbeit, što zvuči neobično, ali razumljivo. Ne možemo promijeniti činjenicu da SOUR nije bio $\mathrm{GmbH}$. Ne možemo se čak ni praviti da je to bio isti model kao VEB (volkseigener Betrieb u DDR-u), što bi na hrvatskom bilo nešto poput „narodno poduzeće“ ili preciznije „poduzeće u narodnom vlasništvu“.

\subsection{EUR-LEX $i$ zdravlje}

Vrijedan izvor političkih, pravnih, ali i drugih stručnih termina danas je EURLex u kojem se zahvaljujući marljivom radu prevoditelja, pravnika-lingvista (zapravo bi trebalo reći pravnika-jezičara) i terminologa okupio lijep korpus europskih propisa i na hrvatskom jeziku. Pretraga je vrlo jednostavna, ali ponekad ni taj izvor nije pouzdan. Naime, zbog određene pomutnje oko izraza "zdravlje“ i „zdravstvo" u hrvatskom nazivlju koje je nastupilo nakon što je hrvatsko Ministarstvo zdravstva kratkotrajno preimenovano u Ministarstvo zdravlja, što je u međuvremenu vraćeno na staro, smatralo se da zbog toga i zdravstveni sustav kao takav može biti zamijenjen „zdravljem“. EUR-Lex tako u nekim dokumentima za pojam Gesundheitswesen na hrvatskom bilježi „zdravlje“, iako ne dosljedno kao što se vidi na sljedećem primjeru:

Komisijina Zelena knjiga (COM(2008) 725 final) o radnoj snazi EU-a za zdravlje

Grünbuch der Kommission (COM(2008) 725 endg.) über Arbeitskräfte des Gesundheitswesens in der EU

Ipak za Gesundheitsberufe nalazimo "zdravstvenu radnu snagu“, a za Arbeitskräfte des Gesundheitswesens javljaju se "zdravstveni radnici“.

Prevoditelj koji bi se slijepo pouzdao u naziv ovog dokumenta iz EURLexa zaista bi mogao doći na ideju da se na hrvatskom ne može koristiti izraz „zdravstvo“. Pritom je upravo u tom semantičkom polju oko zdravlja i zdravstva hrvatski jezik vrlo praktičan i precizan, zapravo bogatiji nego engleski, u kojem velik dio ovog semantičkog polja pokriva jedinstveni 
pojam health, ili njemački, kojemu je i samome Gesundheitswesen često toliko nezgrapan da ga u složenicama krati na Gesundheits-.

O nazivima resora ministarstava možemo usputno konstatirati da su u svim zemljama podložni čestim promjenama, stoga je nepotrebno tražiti stroge paralelizme i usmjeriti se na adaptacije, već je pametnije doslovno prenijeti elemente naziva ministarstva o kojemu se radi.

\subsection{Regierungspräsident nije Regierungschef}

Posljednji primjer koji navodimo je njemački pojam „,Regierungspräsident“, za koji mnogi pogrešno smatraju da se radi o predsjedniku vlade, pa čak i u ozbiljnim njemačko-hrvatskim rječnicima nailazimo na (dvojako) pogrešan prijevod „predsjednik savezne pokrajine“, kao da se radi o funkciji Ministerpräsident. Doslovnim bismo prijevodom ozbiljno pogriješili, jer je Regierungspräsident $\mathrm{u}$ Njemačkoj načelnik jednog od više vladinih okruga svakoj saveznoj zemlji (Bavarska ih primjerice ima sedam). Po razini ovlasti ta se funkcija može usporediti sa županima u Hrvatskoj, osim što se župani biraju. Prijevod njemačkog Regierungspräsidenta stoga bi trebao biti „načelnik (vladinog) okruga".

Švicarska varijanta Regierungspräsidenta drugi je slučaj, jer se ti dužnosnici biraju i zaista jesu šefovi vlada, ali kantonalnih. Njih bi trebalo prevoditi kao „predsjednika kantonalne vlade“. Ponovno vidimo koliko je važno razumjeti sustav kojemu određeni termin pripada.

\section{ZAKLJUČAK}

Iako će prevoditelj i kod prijevoda specifičnih pojmova pravne ili političke kulture svoje prijevodne strategije podrediti ponajprije ciljnoj situaciji i funkciji teksta, neprijeporno je da njegov prijevod u svakom slučaju treba biti sadržajno točan, razumljiv te da ne smije stvarati pogrešne predodžbe, pa ni na konotativnoj razini. Funkcionalne strategije omogućuju da prijevodne istovrijednice nisu u svim situacijama nužno jednako detaljne i specifične, ali to ne znači da opravdavaju odabir netočnog izraza samo zato što taj odgovara navikama ili očekivanjima recipijenta ili zato što ga prevoditelj smatra dostatnim prema onome što procjenjuje glavnom namjerom izvornoga teksta. Recipijent prijevoda mora dobiti sadržajno pouzdanu informaciju upravo o pojmovima koji su kulturno specifični, i to ne samo onda kada je to i primarna funkcija teksta, jer bi to s jedne strane bitno suzilo ravnopravnost recipijenta prijevoda $u$ odnosu na recipijenta izvornog teksta, a s druge bi značajno ograničilo mogućnosti svestranog implicitnog učenja koje bi čitanje bilo kojeg teksta trebalo omogućiti. Stoga smatramo da se prevoditelj kako bi ispunio svoju osnovnu ulogu posrednika među kulturama ponekad mora odlučiti na prijevodna rješenja kojima će recipijenta i poučiti. 


\section{LITERATURA}

Catford, J. C. (1965) A linguistic theory of translation; an essay in applied linguistics. London: Oxford University Press.

De Groot, G. R.. (1991) Recht, Rechtssprache und Rechtssystem: Betrachtungen über die Problematik der Übersetzung juristischer Texte. Terminologie et Traduction 1991 (3), 279-316. http:// digitalarchive.maastrichtuniversity.nl/fedora/get/guid:b8802ff9-8ef3-44f9-8190-54f944b3f3ba/ ASSET1 (preuzeto 22. 7. 2019.).

De Groot, G. R. (1999) Zweisprachige juristische Wörterbücher. U Sandrini, P. (ur.) Übersetzen von Rechtstexten: Fachkommunikation in Spannungsfeld zwischen Rechtsordnung und Sprache. Tübingen: Günter Narr, 203-227.

Europski sud, Mišljenjenezavisnog odvjetnika MANUELACAMPOSASÁNCHEZBORDONEod 26. rujna 2018., predmet C492/17. http://curia.europa.eu/juris/document/document.jsf?text=\&docid=206121\&pageIndex=0\&doclang=HR\&mode=lst\&dir=\&occ=first\&part=1\&cid=1103941 $(29$. 3. 2019.).

Grimm, J. u. W. (1893) Deutsches Wörterbuch, Bd. 14, Sp. 573. http://woerterbuchnetz.de/cgi-bin/WBNetz/wbgui_py?sigle=DWB\&mode=Vernetzung\&lemid=GR02995\#XGR02995 (29. 3. 2019.).

Hansen, D. (1996) Zum Übersetzen von Kulturspezifika in Fachtexten. U Kelletat, A. F. (ur.) Übersetzerische Kompetenz. Beiträge zur universitären Übersetzerausbildung in Deutschland und Skandinavien. Frankfurt a. M., Berlin, Bern, New York, Paris, Beč: Peter Lang, 63-78.

Hudeček, L. i Mihaljević, M. (2012) Hrvatski terminološki priručnik. Zagreb: Institut za hrvatski jezik i jezikoslovlje.

Ivir, V. (1987) Procedures and strategies for the translation of culture. Indian Journal of Applied Linguistics 13 (2), 35-46.

Lütze-Miculinić, M. (2004) Njemački toponimi i njihove izvedenice u hrvatskome književnom jeziku na primjeru imena njemačkih saveznih zemalja i njihovih glavnih gradova. Suvremena lingvistika, 57-58 (1-2), 1-12.

Markstein, E. (2006) Realia. U Snell-Hornby, M., Hönig, H. G., Kußmaul, P. i Schmitt, P. A. (ur.) Handbuch Translation. Tübingen: Stauffenburg, 288-291.

Newmark, P. (1988) A textbook of translation. New York: Prentice-Hall International.

Pavlović, N. (2015) Uvod u teoriju prevođenja. Zagreb: Leykam international.

Petrak, M. (2014) Rimska pravna baština u Hrvatskoj. Hrvatska revija 2. http://www.matica.hr/ hr/428/rimska-pravna-bastina-u-hrvatskoj-23763/ (29. 3. 2019.).

Reiß, K. i Vermeer, H. J. (1984) Grundlegung einer allgemeinen Translationstheorie. Tübingen: Niemeyer.

Sandrini, P. (1996) Terminologiearbeit im Recht: Deskriptiver begriffsorientierter Ansatz vom Standpunkt des Übersetzers. Wien: Termnet Internationales Institut für Terminologieforschung.

Sandrini, P. (1999) Translation zwischen Kultur und Kommunikation: Der Sonderfall Recht. U Sandrini, P. (ur.) Übersetzen von Rechtstexten: Fachkommunikation im Spannungsfeld zwischen Rechtsordnung und Sprache. Tübingen: Günter Narr, 9-43.

Stolze, R. (1992) Rechts- und Sprachvergleich beim Übersetzen juristischer Texte. U Baumann, K.-D. i Kalverkämper, H. (ur.) Kontrastive Fachsprachenforschung. Tübingen: Günter Narr, 223-230.

Šarčević, S. (1989) Conceptual Dictionaries for Translation in the Field of Law. International Journal of Lexicography 2 (4), 277-293. 


\section{TRANSLATING SPECIFIC ELEMENTS OF POLITICAL AND LEGAL CULTURE IN GERMAN AND CROATIAN}

Using various examples such as Bundesland or Javni Pravobranitelj, this paper analyzes the problems a translator encounters when translating Croatian or German political or legal terms for which the other language does not have adequate parallel concepts or equivalents. As essential preconditions for a good translation it identifies thorough knowledge of the respective legal and political systems as well as of relevant terminologies, specific competences regarding meaning and homonymy and connecting a specific term with the proper political or legal system, good assessment of understandability and not refraining from a certain amount of learning through translation. The paper also highlights several frequent mistakes and the possible motivation leading to incorrect translations of political and legal terms.

Keywords: translating German and Croatian political and legal terms, homonymy, political or legal system, understandability, exoticism 